\title{
Varicella Zoster Virus IgM Antibody Measurement
}

National Cancer Institute

\section{Source}

National Cancer Institute. Varicella Zoster Virus IgM Antibody Measurement. NCI

Thesaurus. Code C98797.

The determination of the amount of varicella zoster virus IgM antibody present in a sample. 